\title{
Foreign Participation and Its Relationship with Non-Life Insurer Performance in the Northeast Asian Markets
}

\author{
Yu-Luen $\mathrm{Ma}^{\mathrm{a}}$, Nat Pope ${ }^{\mathrm{a}}$ and Raymond Yeung ${ }^{\mathrm{b}}$ \\ ${ }^{a}$ Katie School of Insurance and Financial Services, Illinois State University, Normal, IL 61790-5490, U.S.A. \\ ${ }^{\mathrm{b}}$ Australia and New Zealand Banking Group (ANZ), Level 22, Three Exchange Square, 8 Connaught Place, \\ Central, Hong Kong.
}

This research examines the relationship shared by a national insurance market's competitive structure and insurer profitability. For these purposes, a market's competitive structure is defined by the level of foreign presence and market concentration. The analysis focuses on the four major non-life insurance markets of Asia: Japan, the People's Republic of China, South Korea and Taiwan. The analysis tests hypotheses derived from the broad body of theory generally referred to as the structure-conductperformance $(S C P)$ hypothesis. The methodological approach makes a significant improvement over previous related work in that it also includes insurer-level data in additional to market-level control variables. In doing so, this research holds out the potential for consideration in the development of insurer-specific strategies in light of a potential influx of foreign competitors. The key findings of this research include general support for the expectations of the SCP hypothesis that predicts dominant firms in concentrated markets will drive up product price and generate associated higher levels of profit.

The Geneva Papers (2013) 38, 43-61. doi:10.1057/gpp.2012.20

Keywords: Asia; insurer profitability; foreign participation; market competitiveness

Article submitted 25 July 2011; accepted 27 February 2012; published online 25 April 2012

\section{Introduction}

The Asian non-life insurance marketplace represents approximately 13 per cent of the global market. Of that percentage, the four largest Asian markets (the People's Republic of China (PRC), South Korea, Japan and Taiwan) represent about 84 per cent (11 per cent of the global market). In addition to their dominant position within the Asian insurance market, these four economies also share a geographical proximity, representing what is considered to be Northeast Asia. Given the magnitude of their collective market and the continuing liberalisation of international trade, foreign insurers understandably have a keen interest in the potential profit those markets might represent. Simultaneously, domestic insurers have a keen interest in the implications associated with the presence of foreign insurers and the threat they might represent.

This research assesses the relationship foreign presence shares with insurer profitability in the non-life insurance marketplace in Northeast Asia. The findings 
will be of keen interest to both domestic and foreign insurers already operating in those markets as well as to insurers contemplating establishing a presence. Additionally, given the roles of regulators and national policymakers in shaping the competitive nature of its markets, they too will be interested in these findings as they may shed light on the implications of their deliberations and decision-making. This current research makes two significant improvements over earlier related research. First, we use company-level data from the four markets in the analysis. Previous studies examining international insurance market issues have traditionally relied on country-level data due to the lack of firm-specific data across national markets. ${ }^{1}$ Our use of company-level data allows for control of factors that contribute to the performance of insurers specifically. This level of analysis yields information that insurers themselves may consider in the development of their own strategic plans in the marketplace; earlier analyses only yielded information at the market level, and thus was of greater interest to policymakers and regulators. Second, we use more specific measures of market liberalisation and concentration. This current research uses the percentage of premiums written by foreign insurers to control for the involvement of foreign insurers. Earlier research has frequently relied on less direct measures, such as the International Business Climate (IBC) index, as a means of assessing the accessibility of a given national market. ${ }^{2,3}$ The use of actual foreign presence is a more direct measure of accessibility. Similarly, given the availability of firm-level data in each market, we are able to succinctly assess market concentration in each country directly using a Herfindahl Index (HI). This measure of market concentration is an improvement over other previously used proxies, such as market share based on the top five or top three firms.

Also unique to this research is the application of the Five Forces Model ${ }^{4}$ to the insurance industry. This conceptual framework theorises that market competition is a function of five market forces: the threat of substitute products, the intensity of current rivalries, the threat of new entrants, the bargaining power of suppliers and the bargaining power of customers.

The remainder of the paper is organised as follows. Background information is presented in the subsequent section followed by a review of the pertinent research literature. The data and methodology are then discussed followed by a presentation of the empirical results. The paper concludes with a summary discussion of the key findings.

\section{Background}

In recent decades, the global economy has consistently moved towards greater deregulation and liberalisation, thereby promoting increasingly competitive national

\footnotetext{
${ }^{1}$ See, for example, Pope and Ma (2008) and Ye et al. (2009).

${ }^{2}$ Previous research that used IBC index to measure the level of market liberalisation include Ma and Pope (2003, 2008) and Ye et al. (2009).

${ }^{3}$ The IBC Index is generated by the Political Risk Services Group (www.prsgroup.com) and is based on a number of factors that evaluate a nation's business environment for international firms.

${ }^{4}$ Porter (1980).
} 
markets. Nowhere have these efforts been more evident than in the global financial marketplace, including the insurance industry. ${ }^{5}$ The 1986-1994 Uruguay Round of trade negotiations formalised early global liberalisation efforts. Specific attention to financial services (and the insurance industry in particular) was addressed in the Agreement on Financial Services section of those negotiations. With over 142 signatory nations, this statement of goals and objectives for an open and competitive global marketplace received significant support. Economic theory predicts that open and competitive markets will encourage the creation of an environment in which market forces freely determine appropriate pricing, supply and profitability. Indeed, the presence of an open and competitive insurance market has been found to be positively related to the economic growth of a national economy-especially in the emerging markets. ${ }^{6}$ Deregulation is also expected to help liberalise a market, attract foreign entrants and play a role in further market evolvement. ${ }^{7}$ However, the actual impact of increased foreign presence on the performance on insurers remains unclear and has received relatively scant attention in the earlier literature.

\section{The major markets of Asia}

As noted earlier, the markets of Northeast Asia dominate the Asian insurance landscape and represent a significant segment of the global non-life insurance marketplace. While much of the rest of the world has steadily coalesced into regional blocks, for example North American Free Trade Agreement, the European Union, etc., the major economies of Northeast Asia have resisted similar formal alignment for a variety of reasons, including differing political philosophies, historical, cultural biases, etc. More recently, however, the markets of Northeast Asia have come under increasingly heavy strain as economic regionalism elsewhere has made strong gains. ${ }^{8}$ Thus, an examination of economic dynamics within this regional block at this time may actually anticipate future events that may formalise the economic relationships among these markets.

Beyond their geographic proximity and their dominant insurance positions in the Asian region, these countries represent a diverse group in terms of their market histories, size, competitive structure, etc. Table 1 presents a brief statistical summary of the Asian market that includes market share (on a global basis) and two common measures of insurance market development, insurance penetration and density. The former is a rough measure of the relative importance of insurance within a national economy and is determined by dividing a national market's aggregate premium revenues by the nation's gross domestic product (GDP). Insurance density assesses the extent to which a national population purchases insurance and is determined by dividing aggregate premium volumes by a nation's population.

\footnotetext{
${ }^{5}$ Swiss $\operatorname{Re}(2008)$.

${ }^{6}$ Arena (2008), Zheng et al. (2009), Ćurak et al. (2009), Avram et al. (2010) and Chen et al. (2011).

${ }^{7}$ Skipper (2001).

${ }^{8}$ Aggarwal and Koo (2006) present an historical framework that describes the motivation for the traditional bilateral types of agreements preferred by those markets and go on to describe the rationale for a more cohesive regional economic block in the near future.
} 
Table 1 Comparative statistical profiles ${ }^{\mathrm{a}}$

\begin{tabular}{|c|c|c|c|}
\hline Market & Global market share (\%) & Penetration & Density \\
\hline Japan & 7.6 & 2.21 & 685.8 \\
\hline $\mathrm{PRC}$ & 1.4 & 0.95 & 14.5 \\
\hline South Korea & 1.6 & 3.01 & 418.5 \\
\hline Taiwan & 0.7 & 1.42 & 364.9 \\
\hline Northeast Asia & 11.4 & 1.91 & 24.8 \\
\hline Asia & 13.5 & 1.70 & 46.6 \\
\hline Industrialised countries ${ }^{b}$ & 89.2 & 3.71 & $1,217.3$ \\
\hline Emerging markets ${ }^{\mathrm{c}}$ & 9.8 & 1.37 & 26.8 \\
\hline World & 100.0 & 3.20 & 207.3 \\
\hline
\end{tabular}

${ }^{\mathrm{a}}$ Values presented are averages derived from the 2000-2008 period data.

${ }^{\mathrm{b}}$ Industrialised countries include: North America, Western Europe (excluding Turkey), Japan, Hong Kong, Singapore, Oceania and Israel.

${ }^{\mathrm{c}}$ Emerging markets include: Latin America, Central and Eastern Europe, South and East Asia, the Middle East (excluding Israel), Turkey, Central Asia and Africa.

Data source: Swiss Re, Sigma, various annual world insurance summary reports.

As can be seen from Table 1, Japan, South Korea and Taiwan all possess insurance density estimates that are more similar to industrialised nations while the PRC's value (14.5) is relatively weak, even when compared to emerging markets (26.8). A similar story unfolds with respect to insurance penetration with the exception that Taiwan's penetration (1.42) aligns more closely with the emerging markets than the developed countries. Also evident is the relatively large global market share possessed by Japan (7.6 per cent). As of 2008, Japan was the fourth largest non-life insurance market in the world while the PRC was number ten, South Korea was number 12 and Taiwan was number $18 .^{9}$

Foreign presence differs significantly across the four economies. Foreign insurers represent about 27 per cent of Taiwan's non-life market while the presence is far smaller in South Korea (about 4 per cent) and in the PRC and Japan, where foreign insurers represent about 1 per cent of the non-life market share in each of those economies. Thus, the foreign presence in each of the latter three markets represents significant potential for increase.

\section{Defining market competition}

The notion of market competition is a multi-dimensional concept. It may reveal itself in terms of price levels, the number of competitors, mergers and acquisitions, etc. In an effort to refine our definition of competition at the market level, we adopt Porter's Five Forces Model as a framework for the assessment. ${ }^{4}$ The model draws upon the economics of industrial organisation in identifying five forces that determine the competitive intensity and attractiveness of a given marketplace. While the applications

\footnotetext{
${ }^{9}$ Swiss Re (2009).
} 
of the model may be many, our concern is its ability to rationally identify a set of forces that may impact the development of strategic planning at the insurer level. It should be noted that the overall competitiveness of a given industry does not assure all participants of a similar level of profitability; there may be (indeed likely) winners and losers. The task at hand for insurers is to correctly assess the competitive character of their industry and leverage their specific competitive advantages in competing successfully.

The five forces are identified as: the threat of substitute products, the intensity of current rivalries, the threat of new entrants, the bargaining power of suppliers and the bargaining power of customers. The first three of these forces refer to competition from external sources, while the latter two are considered internal forces. Within the traditional industrial organisation framework, external forces can be thought of as influence defined by the marketplace and that affect all competitors, albeit to possibly differing degrees. Conversely, internal forces can be thought of as being more company specific, characteristics that possess a unique relationship with given firms. However, when contemplated within the context of the insurance industry, the delineation between forces becomes a bit blurred on occasion-an issue we address below. We now consider each of the five forces in turn, with their specific applicability to the non-life insurance industry and this research.

\section{Threat of new entrants}

The threat of entry into the insurance market may come both from within and from outside national boundaries. Recent deregulation in many national markets have allowed competitors from domestic financial services industries, for example banking, insurance, etc., to enter one another's markets. Thus, a market's regulatory structure may impact the threat of new entrants from within national boundaries. For example, in the late 1990s the Japanese insurance market experienced a removal of intrainsurance industry barriers, thereby allowing domestic life and non-life insurers to create subsidiaries and compete on a cross-market basis. Subsequently, ostensible barriers to the entry of foreign insurers were also removed by 2000 , thereby allowing relatively more freedom to foreign insurers interested in entering the marketplace.

The threat of foreign entry represents a special challenge to a domestic market, as opposed to domestic competition. The fact that foreign insurers must often overcome significant regulatory hurdles merely to gain entrance to a foreign national market implies that the insurer likely believes it possesses significant/sufficient competitive advantages, relative to the domestic market-otherwise why expend the effort and expense? ${ }^{10,11}$

\footnotetext{
${ }^{10}$ Skipper (1998).

${ }^{11}$ Moshirian (1997) provides insight into the characteristics of the U.S. economy that serve to attract foreign direct investment in insurance services, while Ma and Pope (2003) found that market concentration and low-barriers-to-entry shared positive relationships with foreign insurer presence in OECD (Organisation for Economic Co-operation and Development) countries.
} 
Threat of substitute products or services

Within the insurance context, alternative services and products are limited in scope and feasibility. The foremost alternative would be risk retention. A variation on that theme would be the implementation of risk management measures that change the character of the risk, but the net result is still the retention of the financial responsibility for the risk. At the extremes, large risks might be able to enter the capital markets in search of a solution.

Intensity of current rivalries

Porter $^{12}$ notes that the intensity of industry rivalries is highest when there are numerous competitors of relatively similar size. Additionally, slow growth also encourages a fight for market share among existing competitors.

\section{Bargaining power of suppliers}

The "raw" material for insurance may be conceived of in a number of ways. Certainly, the industry functions on capital and cash flow. The two primary sources of insurer funds are premium revenues and investment income. Reinsurance is also considered as an alternative source of shareholder capital in the payment of unexpected losses. To a lesser degree, innovative mechanisms by which the capital markets are accessed also serve as sources of capital for insurers. While the conceptualisation of the customer-assupplier has validity, that source of capital is highly fragmented and lacks any cohesive bargaining power. While the investment market also stands ready as a supplier of capital, it interacts with the insurance industry in essentially the same manner it does with all other investors; the price of its capital rises and falls on an economy-wide (even global) basis.

The availability of reinsurance in the marketplace approximates the role of a supplier of raw materials in the insurance market that might seek to negotiate the cost of the product it provides. While there are indeed times when capacity is relatively scarcer and relatively more expensive, such as in the case in a hard market, the global reinsurance market is generally sufficiently competitive to ensure a competitive negotiation between the insurer and reinsurer.

\section{Bargaining power of buyers}

Given the traditional plethora of consumers of insurance in the marketplace (both at the personal and commercial levels), no single consumer (or small group of consumers) is likely to possess sufficient leverage to significantly impact the balance of market dynamics. That is not to say that some large commercial accounts may not have significant leverage in negotiating their own contracts with the marketplace. However, such power is limited in scope and is highly unlikely to impact the broader market, for example, by forcing an industry-wide reduction in property insurance rates. More typically, consumers of insurance are what might be thought of as "price-takers".

\footnotetext{
${ }^{12}$ Porter (2008).
} 


\section{Literature review}

The examination of the relationship shared by a market's concentration and its level of competitiveness is not new. The earliest specific research on the topic can be traced to Bain, ${ }^{13}$ who developed the concentration-profits hypothesis. As a derivation from more conventional price theory, the concentration-profits hypothesis anticipates that a market with higher levels of market share concentration would encourage oligopolistic behaviour by dominant competitors. Subsequently, Stigler ${ }^{14}$ adapted and slightly modified Bain's work in more formally developing the collusion theory. The surrounding and ensuing body of associated literature eventually coalesced into what is now collectively understood to be the structure-conduct-performance (SCP) hypothesis. ${ }^{15}$ The SCP hypothesis predicts that dominant firms in relatively more concentrated markets will set prices that are less favourable to consumers because of imperfect competition. ${ }^{16}$ Given the price leadership position of dominant firms, smaller competitors are able to adopt similar pricing strategies resulting in an overall increase in industry price levels and associated profitability. Much of the early manufacturing research in the U.S. markets found support for the SCP hypothesis. ${ }^{17}$ Related research focusing on foreign manufacturing data bore similar results. ${ }^{18}$

With respect to the available financial market literature, the results are less conclusive. In their examination of the European banking industry, Molyneux and Teppet $^{19}$ find support for the SCP hypothesis. Pilloff and Rhoades ${ }^{20}$ find similar support using U.S. metropolitan statistical area level data. Conversely, a few banking studies find a negative relationship between market concentration and profitability. ${ }^{21}$ The insurance literature specifically addressing the concentration-profitability relationship is limited and is heavily focused on the U.S. market. Joskow ${ }^{22}$ examines the competitive market structure of the non-life insurance marketplace and concludes that the combination of state regulation, pervasive cartel pricing and other market peculiarities results in significant inefficiencies. Bajtelsmit and Bouzouita ${ }^{23}$ examine the market concentration-profitability relationship within the auto insurance marketplace and find a significant positive relationship, supporting SCP hypothesis expectations. Chidambaran et $a l .{ }^{24}$ examine the relationship across various lines of non-life insurance and find support for a positive relationship, concluding that the structure and characteristics of the marketplace contribute to a reduced level of competition

13 Bain (1951).

${ }^{14}$ Stigler (1964).

15 Tsutsui et al. (2006).

${ }^{16}$ See Feuerstein (2005) for a current survey of the associated body of literature using industrial sector data.

${ }^{17}$ Collins and Preston (1969), Weiss (1974) and Peltzman (1977).

${ }^{18}$ See, for example, Caves and Uekusa (1976), Jenny and Weber (1976) and Neumann et al. (1985).

${ }^{19}$ Molyneux and Teppet (1993).

${ }^{20}$ Pilloff and Rhoades (2002).

${ }^{21}$ Jacquemin et al. (1980) and Clarke (1984).

22 Joskow (1973).

23 Bajtelsmit and Bouzouita (1998).

${ }^{24}$ Chidambaran et al. (1997). 
among insurers. Carroll's ${ }^{25}$ assessment of the market concentration-profitability relationship in the U.S. workers compensation market did not find a relationship, although the highly regulated nature of that line of business may contribute to those findings. ${ }^{26}$

More recently, Pope and $\mathrm{Ma}^{27}$ examine the relationship at the national level using OECD data. Their examination of the issue includes a control for the interaction of market concentration and the level of foreign access to a given national market, a variable that is found to share a complex relationship with the market's profitabilitya finding anticipated by the $S C P$ hypothesis. Bain ${ }^{28}$ notes the importance of considering the competitive character of a market by simultaneously considering the existing barriers to entry and exit. Despite that early insight, few researchers have pursued an investigation of this interaction, and for those who have, the results have been mixed. Using industrial sector data, a few authors find support for a positive relationship between profitability and the interaction of market concentration and barriers-to-market entry. ${ }^{29}$ However, Orr ${ }^{30}$ finds only marginal evidence that interactive specification provides superior results when compared to independent specification. While not formally interacting the terms, Clark and Speaker ${ }^{31}$ find that the impact of market concentration on bank profitability is greater when entry conditions are less favourable. These findings mirror the results of $\mathrm{Harris}^{32}$ who finds that price-cost margins in the industrial sector are positively related to the existence of entry barriers. Berger et $a l^{33}$ find that market concentration and impediments to competition are associated with high profits in the banking industry.

$\mathrm{Ma}$ and Pope $^{34}$ examine a variation on the general theme and find a significant relationship between the interaction variable (market concentration and liberalisation) and the presence of foreign insurers (as opposed to profitability). Their results suggest that a highly liberalised market environment will significantly mitigate the negative relationship related to the presence of foreign insurers and market concentration.

\section{Data and methodology}

Data

Our data was obtained from various publications of the regulators, insurance institutes and insurance associations of the respective national markets. We use

${ }^{25}$ Carroll (1993).

${ }^{26}$ Cummins et al. (1972) examined the relationship in the U.S. life insurance market and reported that market concentration and competition were inversely related, implying a positive relationship between market concentration and profitability.

${ }^{27}$ Pope and Ma (2008).

${ }^{28}$ Bain (1956).

${ }^{29}$ Mann (1966), Qualls (1972) and Jenny and Weber (1976).

${ }^{30}$ Orr (1974).

${ }^{31}$ Clark and Speaker (1992).

${ }^{32}$ Harris (1986).

${ }^{33}$ Berger et al. (2000).

${ }^{34} \mathrm{Ma}$ and Pope (2003). 
Table 2 Basic statistics of variables

\begin{tabular}{|c|c|c|c|c|}
\hline Variable & Mean & Std. dev. & Min. & $\operatorname{Max}$ \\
\hline PROFITABILITY & 0.917 & 0.180 & 0.220 & 1.667 \\
\hline MARKET CONCENTRATION & 0.178 & 0.072 & 0.090 & 0.386 \\
\hline FOREIGN PRESENCE & 0.078 & 0.099 & 0.010 & 0.361 \\
\hline$R I V A L R Y$ & 0.180 & 0.075 & 0.089 & 0.735 \\
\hline$D E M A N D$ & 0.020 & 0.008 & 0.009 & 0.036 \\
\hline DIVERSITY & 57.069 & 968.323 & 0.000 & $16,884.060$ \\
\hline POWER & 0.069 & 0.100 & 0.000 & 0.859 \\
\hline$S I Z E$ & 1961.980 & 3919.690 & 0.581 & $21,103.630$ \\
\hline$A G E$ & 37.872 & 34.682 & 0.000 & 129.000 \\
\hline REINSURANCE & 0.204 & 0.171 & 0.000 & 0.825 \\
\hline
\end{tabular}

Firms less than one year old are identified as having zero years of experience.

Variable definitions: PROFITABILITY $=$ One minus the insurer's combined ratio; $M A R K E T$

CONCENTRATION= Market concentration measured by Herfindahl Index (HI); FOREIGN

$P R E S E N C E=$ Ratio of premiums written by foreign insurers in that market; RIVALRY= Market

competitiveness based on insurer portfolio composition; $D E M A N D=$ Insurance penetration calculated as non-life premiums divided by gross domestic product; DIVERSITY=Diversity of an insurer's bookof-business; $P O W E R=$ Line of business-adjusted market share of an individual firm; SIZE $=$ Total premium volumes of an insurer (in million dollars); $A G E=$ Number of years in operation; REINSURANCE= Ratio of premiums ceded to a reinsurer.

firm-level data and our sample covers the time period 2003-2008. Table 2 presents the variable summary statistics.

\section{Variable discussion}

Our dependent variable is firm-level profitability and is proxied as one minus the insurer's combined ratio (PROFITABILITY). ${ }^{35}$ This measure has been adopted as a proxy for insurer profitability in earlier research. ${ }^{36,37}$

Our independent variables include a mix of both market- and firm-level data. Our primary interest relates to the relationship shared by the threat that foreign entry shares with insurer profitability in a given market. ${ }^{38}$ We control for the threat of foreign insurer entry by directly assessing the current presence in the marketplace. This presence is measured by the aggregate net premiums written by foreign insurers (as a

${ }^{35}$ Insurers in all four markets included in this study follow the same accounting principles in booking their revenues on a line-of-business basis. Additionally, they also follow the same claims adjustment practices, and thus the combined ratios, our measure of profitability, should be comparable.

${ }^{36}$ See, for example, Goldberg and Rai (1996), Chidambaran et al. (1997), Bajtelsmit and Bouzouita (1998) and Pope and $\mathrm{Ma}$ (2008).

${ }^{37}$ This approach reflects Cowling and Waterson's (1976) theoretical estimation of firm profitability that was first adapted for application to the insurance industry by Carroll (1993).

${ }^{38}$ Browne et al. (2000) report a positive relationship between market share of foreign insurers and general liability insurance consumption. Li et al. (2007) also find foreign market share to be associated with insurance sales. 
percentage of the total premiums written) in that market (FOREIGN PRESENCE). Foreign insurers in Taiwan and Japan have, on average, higher levels of profitability than do domestic insurers in those markets. The relationship is reversed in the PRC and South Korea.

Also of significant interest is the intensity of a given economy's marketplace rivalry. Porter ${ }^{12}$ suggests that the intensity is greatest when there are numerous competitors of roughly equal size. We control for market concentration using the HI (MARKET CONCENTRATION) based on premium volumes. ${ }^{39}$ Recognising the potential implications for insurer profitability with regard to barriers to entry and a market's competitive structure, we also include an interaction term that controls for the foreign presence and market concentration (FOREIGN PRESENCE $\times$ MARKET CONCENTRATION).

Earlier research has consistently found that the strength of a nation's economy is positively associated with demand for non-life insurance products. ${ }^{40}$ Demand, along with supply, is a key component in classic pricing equilibrium theory. ${ }^{41}$ Increases in demand, prior to adjustments in supply, may be accompanied by increases in price leading to higher market profitability in the short term. However, subsequent to supply-side adjustments, such profitability is expected to disappear due to competition in the marketplace. This scenario would be particularly acute during periods of rapid economic growth. The opposite would also be true during periods of contraction in market demand. Thus, the impact of the economy on profitability may be either positive or negative, depending on market conditions and how quickly supply is able to adjust. Arena ${ }^{42}$ and Haiss and Sumegi ${ }^{43}$ find that insurance penetration is positively related to a market's economy growth and, thus, the demand for insurance products. We control for this effect by including insurance penetration, which is calculated by dividing non-life premiums by GDP (DEMAND).

One of the greatest challenges facing prior international insurance market studies has been the lack of firm-specific data across national markets. It must be noted that the efficient structure (ES) hypothesis has evolved as a competing explanation for the positive relationship described by the $S C P$ hypothesis. ${ }^{44}$ Demsetz $^{45}$ suggests that higher profits are the results of firm-specific advantages instead of higher market concentration. While the ES hypothesis has enjoyed significant support in the banking and insurance literature, such analyses require an examination at the firm level. ${ }^{46} \mathrm{~A}$ unique contribution this study makes to the existing body of literature is that it is able to include several crucial firm-level variables that are expected to affect profitability.

${ }^{39}$ The HI is calculated by $\Sigma p_{i}^{2}$, where $p_{i}$ denotes the percentage of the market premiums written by insurer $i$ in that market.

${ }^{40}$ See, for example, Outreville (1990a, b), Beenstock et al. (1988), Browne et al. (2000) and Ma and Pope (2003). Outreville (1996) also finds a positive relationship between GDP and demand for life insurance products. For more discussion on the determinants of life insurance consumption, see Li et al. (2007).

41 Nicholson (1995).

42 Arena (2008).

${ }^{43}$ Haiss and Sumegi (2008).

${ }^{44}$ Brozen (1982).

45 Demsetz $(1973,1974)$.

${ }^{46}$ See, for example, Choi and Weiss (2005). 
For example, earlier research has found that profitability may vary significantly across various lines of insurance because an insurer offering multiple product lines may diversify their risk exposure and also benefit from some forms of economy of scope. ${ }^{47}$ To control for this effect, we construct a variable that identifies the relative diversity of an insurer's book-of-business (DIVERSITY). Because the four markets of Northeast Asia report their statistics associated with lines of business in different manners, we standardise this firm-specific calculation by dividing by the country's diversity index. ${ }^{48}$

The scale of an insurer's operation has been found to share a significant relationship with its performance. While the findings of earlier research have been mixed, a positive relationship between scale and performance appears to dominate. ${ }^{49}$ Conversely, Lai and Limpaphayom ${ }^{50}$ find a negative relationship in their examination of the relationship in the Japanese non-life insurance marketplace. Thus, while the scaleprofitability relationship remains somewhat ambiguous, the need to control for it is evident. We control the scale of an insurer's operation in two ways. First, we control for the relative size of an insurer in a specific line of business using a market power variable that is computed as a weighted-average of the line-specific market share of an insurer. An insurer's respective share of business across each line of insurance is used as a weighting $(P O W E R) .{ }^{51}$ Second, we control for the absolute size of an insurer by including a variable that identifies the total annual net premiums earned by the insurer $(S I Z E)$. Compared to foreign insurers, domestic insurers tend to dominate their respective markets in terms of size.

Additionally, given that insurers may be unevenly affected by the general concentration in the market due to the composition of their business portfolio, we include a firm-level control for market pressure. For example, an insurer may be involved in only a single line of business, for example auto, but may face significant competition in the marketplace. Alternatively, an insurer may be a goliath with a highly diversified portfolio and dominates its competition across many lines. This might be the case, for example, if two insurance monopolies were operating in independent lines of business in a given marketplace. We control for this potential influence by assessing an insurer's exposure to market competitiveness weighted by the insurer's line of business diversity $(R I V A L R Y) .^{52,53}$ In an extreme case, this

${ }^{47}$ Cummins et al. (1972), Cummins and Weiss (1992) and Chidambaran et al. (1997).

${ }^{48}$ Following de Haan and Kates (2010), the relative diversity of an insurer's book-of-business is computed by $\Sigma p_{i j}{ }^{2} / \Sigma p_{c j}{ }^{2}$, where $p_{i j}$ denotes the share of line $j$ premium as a ratio of insurer $i$ 's total book-of-business and $p_{c j}$ is the corresponding index of market $c$.

${ }^{49}$ See, for example, Gardner and Grace (1993), Sommer (1996), Cummins and Nini (2002) and Liebenberg and Sommer (2008).

${ }^{50}$ Lai and Limpaphayom (2003).

${ }^{51}$ Market power is computed by $\Sigma\left[p_{j i} \times p_{i j}\right]$, where $p_{j i}$ denotes the market share of firm $i$ 's line $j$ and $p_{i j}$ measures share of line $j$ premium in firm $i$ 's total business.

${ }^{52}$ Mathematically, competitiveness intensity is computed by $\Sigma\left[p_{i j} \times \Sigma p_{j c}{ }^{2}\right]$ or $\Sigma\left[p_{i j} \times \mathrm{HI}_{j}\right]$ where $p_{i j}$ denotes the share of line $j$ premium income as a ratio of insurer $i$ 's total business and $\mathrm{HI}_{j}$ measures the market concentration (as measured by the HI) for line of business $j$.

${ }^{53}$ The inclusion of other variables controlling for the remaining influences noted in the Five Forces Model are omitted from this analysis as they lack significant application within the insurance industry context, e.g. the bargaining power of buyers and suppliers and the threat of substitute products and/or services. 
adjustment allows for the detection of the absence of competition in a market that may not otherwise be captured by market-level data.

It is also anticipated that an insurer's performance is expected to be positively associated with its length of tenure in the market. Relatively new entrants might be expected to experience a steep learning curve, at least in the first few years. We control for this possible effect by identifying the number of years the insurer has been operating in a given marketplace $(A G E)$.

The use of reinsurance provides the primary insurer with a level of strength and stability that aids in management of the risk assumed in its book of business. That stability would allow an insurer to reduce the risk premium component of the rate charged to the customer, and thus lower its price. Thus, we also include a variable measuring the percentage of premiums ceded to reinsurers (REINSURANCE) in our model.

\section{Methodology}

We assess an insurer's profitability in light of two categories of control variables: (1) market and (2) firm-specific factors. Insurance pricing, and therefore profitability, may be highly correlated from year-to-year, and thus, lagged-insurance-profitability is a logical explanatory variable. Even though the coefficient of the lagged dependent variable may not be of direct interest, estimation using dynamics models may be crucial for obtaining consistent estimates of other parameters. Therefore, we estimate the following model:

$$
y_{i, t}=\alpha y_{i, t-1}+\phi k_{t}+\gamma x_{i, t}+\mu_{i}+\gamma_{i}+\varepsilon_{i, t}
$$

where $y_{i, t}$ represents insurance profitability and $y_{i, t-1}$ is its lagged value. $k_{t}$ is a matrix of market factors, including market concentration, foreign presence and market demand for insurance, and $x_{i, t}$ is a matrix of firm factors, including relative diversity, rivalry, market power, size, age of the firm and reinsurance usage. $\mu_{i}$ and $\gamma_{i}$ are market and company-specific effects, respectively, and $\varepsilon_{i, t}$ is the error term.

When a lagged dependent variable is included in the model, ordinary least squares and static panel data methodologies are biased and inconsistent. Arellano and Bond ${ }^{54}$ and Arellano and Bover ${ }^{55}$ developed the generalised method of moments (GMM) estimators that produce consistent and unbiased coefficient estimates when lagged dependent variables are present. The GMM estimator uses first-differences to transform Eq. (1) into

$$
y_{i, t}-y_{i, t-1}=\alpha\left(y_{i, t-1}-y_{i, t-2}\right)+\phi\left(k_{i, t}-k_{i, t-1}\right)+\gamma\left(x_{i, t}-x_{i, t-1}\right)+\left(\varepsilon_{i, t}-\varepsilon_{i, t-1}\right),
$$

where the individual fixed effects are eliminated from the equation and lagged values of the repressors are now instruments. As a robustness check, we also estimate an alternative panel data fixed-effects model. ${ }^{56}$ To account for serial correlation in

\footnotetext{
${ }^{54}$ Arellano and Bond (1991).

55 Arellano and Bover (1995).

${ }^{56}$ While both fixed-effect and random-effect models yield very similar results, Hausman's test suggests that fixed-effect models are superior to random-effect models in this analysis.
} 
profitability, we assume the covariance structure follows a first-order autoregressive process AR(1). Profitability and other factors may be volatile across time and the true relationship between variables may not be reflected in the analysis without time-series data spanning a broader period. Thus, we also estimated an alternative model by first taking the mean value of all variables across time and conducted a regression analysis based on the mean values. This cross-sectional (CS) analysis on the mean values allows us to assess the long-term effects.

\section{Results}

The empirical results of the analyses are presented in Table 3. Results from GMM, fixed-effects and cross-sectional models are presented in columns 1, 2 and 3,

Table 3 Effect of market concentration and foreign presence on profitability

\begin{tabular}{|c|c|c|c|}
\hline Variable & $G M M$ & $\begin{array}{l}\text { Fixed effects } \\
\text { with } A R(1)\end{array}$ & $\begin{array}{c}\text { Pooled CS with } \\
\text { mean values }\end{array}$ \\
\hline PROFITABILITY $Y_{t-1}$ & $\begin{array}{c}-0.055 \\
(0.088)\end{array}$ & & \\
\hline MARKET CONCENTRATION & $\begin{array}{l}1.165^{* *} \\
(0.543)\end{array}$ & $\begin{array}{l}1.283 * * * \\
(0.361)\end{array}$ & $\begin{array}{l}1.729 * * * \\
(0.645)\end{array}$ \\
\hline FOREIGN PRESENCE & $\begin{array}{l}-2.884 * * \\
(1.300)\end{array}$ & $\begin{array}{l}-2.908 * * * \\
(1.150)\end{array}$ & $\begin{array}{c}-33.082 * * * \\
(7.826)\end{array}$ \\
\hline FOREIGN PRESENCE $\times M A R K E T$ & $39.283 * *$ & $38.274 * * *$ & $412.323 * * *$ \\
\hline CONCENTRATION & $(17.106)$ & $(15.184)$ & $(95.062)$ \\
\hline$R I V A L R Y$ & $\begin{array}{c}0.084 \\
(0.078)\end{array}$ & $\begin{array}{c}-0.011 \\
(0.054)\end{array}$ & $\begin{array}{l}0.676^{* * *} \\
(0.202)\end{array}$ \\
\hline$D E M A N D$ & $\begin{array}{c}-9.799 * * \\
(4.813)\end{array}$ & $\begin{array}{c}-8.101^{* *} \\
(3.710)\end{array}$ & $\begin{array}{l}16.474 * * \\
(6.849)\end{array}$ \\
\hline DIVERSITY & $\begin{array}{c}-0.002 \\
(0.004)\end{array}$ & $\begin{array}{c}-0.005 \\
(0.004)\end{array}$ & $\begin{array}{c}0.024 \\
(0.016)\end{array}$ \\
\hline POWER & $\begin{array}{c}-0.022 \\
(0.015)\end{array}$ & $\begin{array}{c}0.011 \\
(0.014)\end{array}$ & $\begin{array}{l}0.160 * * * \\
(0.038)\end{array}$ \\
\hline$S I Z E$ & $\begin{array}{l}0.196^{* * *} \\
(0.041)\end{array}$ & $\begin{array}{l}0.211^{* * * *} \\
(0.033)\end{array}$ & $\begin{array}{c}-0.045 \\
(0.033)\end{array}$ \\
\hline$A G E$ & $\begin{array}{c}0.040 \\
(0.158)\end{array}$ & $\begin{array}{c}0.179 \\
(0.112)\end{array}$ & $\begin{array}{c}0.057 \\
(0.038)\end{array}$ \\
\hline REINSURANCE & $\begin{array}{c}-0.041 \\
(0.098)\end{array}$ & $\begin{array}{c}-0.110 \\
(0.123)\end{array}$ & $\begin{array}{c}-0.501 \\
(0.317)\end{array}$ \\
\hline-2 Log likelihood & & -328.6 & \\
\hline $\operatorname{Adj}-R^{2}$ & & & 0.649 \\
\hline Wald $\chi^{2}$ & 114.29 & & \\
\hline Number of observations & 215 & 356 & 74 \\
\hline
\end{tabular}

${ }^{a}$ Standard errors are heteroscedasticity and autocorrelation consistent. Robust standard errors are reported in the parentheses below coefficient estimates. Country-specific intercepts, company-specific intercepts and year dummy variables are included in the fixed-effects models, but are not reported here. The year dummy variables are also included in the GMM model, but are not reported here.

$*, * *$ and $* * *$ indicate significance at $10 \%, 5 \%$ and $1 \%$ levels, respectively. 
respectively. The main results from all three models are consistent with each other, confirming the significant link between market concentration, foreign presence and profitability. A variance inflation factor assessment of each model reveals that there are no issues associated with multi-collinearity. The key variables, MARKET CONCENTRATION and FOREIGN PRESENCE, are statistically significant across all three models with consistent signs. The coefficients associated with MARKET CONCENTRATION are found to be positively significant, while the coefficients for FOREIGN PRESENCE are negatively significant. The interaction terms of these two variables are positively significant with a large coefficient, suggesting that the relationship between market concentration (foreign presence) and firm profitability is contingent upon the level of foreign presence (market concentration). Using the coefficients from the GMM model, Figure 1 relates an insurer's profitability to the market's competitive profile. As defined by the market concentration-foreign presence plane, corner A characterises a market profile where foreign presence is high and market share is highly diffused. Similarly, corner B reflects high levels of foreign presence but with high market concentration. Corner $\mathrm{C}$ characterises a market with low levels of foreign presence with high market concentration. Last, corner D reflects a market with low levels of foreign presence and low market share concentration.

As anticipated by the SCP hypothesis, higher levels of market concentration are indeed associated with higher levels of insurer profitability (corner C). This positive relationship is magnified when the market also has a relatively greater foreign presence. At the extreme, corner B graphically reveals the interaction of the three variables. Conversely, the lowest levels of market concentration and foreign presence are associated with the lowest levels of insurer profitability (corner D). Additionally, the relatively low slope of the front edge of the figure moving along the foreign presence-axis (corner D to corner A) reveals that increased levels of foreign participation in an otherwise diluted marketplace is only weakly associated with

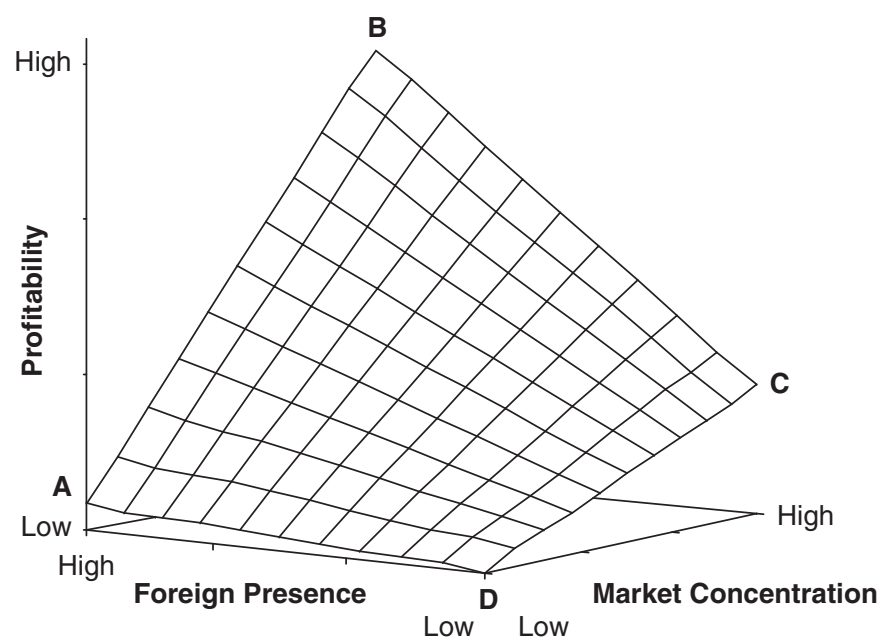

Figure 1. Interactive relationship of market concentration and foreign presence on profitability. 
insurer profitability. Markets with relatively low levels of foreign participation but which are moderately more concentrated (the axis associated with corners D and C) are associated with similarly higher levels of insurer profitability.

Several other control variables were also found to be significant and yield consistent results in both the GMM and the fixed-effects model. Insurance demand (DEMAND) was found to share a negative relationship with profitability, which suggests that insurers in markets with higher insurance penetration have lower profit margin. Insurance penetration may be indicative of the maturity of the insurance market. Insurance profit margin may be expected to be lower in markets that are mature and fully developed. The coefficient of the size variable $(S I Z E)$ is found to be positively significant, suggesting that larger insurers enjoy higher profits. Interestingly, the coefficients of two control variables, RIVALRY and POWER, were found to be statistically significant only in the pooled cross-sectional model. Given the lack of significant inter-temporal changes for these two variables and the nature of the established markets of Japan, Korea and Taiwan, these results are to be expected. Line-specific market shares of individual insurers, the key inputs to constructing these two variables, have varied little over the period under investigation. Therefore, the AR(1) specification seems to have some challenges in identifying the effect on temporal change in insurers' performance. Additionally, the coefficient for the $D E M A N D$ variable is positively significant in the pooled cross-sectional regression, while negative in the time-series analysis. This is again attributed to the fact that insurance penetration has not had major variation over time. The results do offer strong support for the following variables and their long-term association with insurer performance: rivalry based on the insurer's composition of its portfolio (RIVALRY), an insurer's market power $(P O W E R)$ and a market's insurance penetration $(D E M A N D)$.

\section{Summary}

This research assesses the relationship that insurer profitability shares with specific aspects of market structure and focuses on the interaction of foreign participation and market concentration. The analysis focuses on the Northeast Asian marketplace that includes the four largest Asian insurance markets: Japan, the PRC, South Korea and Taiwan. We find that the profitability of insurers in these markets shares a complex and dynamic relationship with respect to the interaction of foreign presence and market concentration.

These findings have unique importance to insurers contemplating market entry in one or more of the Northeast Asian economies. Market regulators have the ability to encourage/discourage domestic market concentration through regulation and statutes such as those that govern merger and acquisition activities. Policymakers, on the other hand, control the ability of foreign competitors to enter a national market. Understanding the character of the complex relationship, market concentration and foreign participation share with respect to profitability allows insurers (both foreign and domestic) to interpret regulator and policymaker behaviour as indicators of potential future levels of profitability, a matter of significant importance in strategic 
planning. Given the shared cultural heritage and history of much of Asia, these findings may also find specific application in other developed and emerging economies in the region.

While much work remains to be done related to the implications associated with the emergence of Northeast Asia as a regional economic block, this current research provides a unique glimpse into what promises to be a dynamic, growing and evolving player in the global economy.

\section{References}

Aggarwal, V.K. and Koo, M.G. (2006) Institutional Path to Security and Economic Cooperation in Northeast Asia, Conference presentation, Northeast Asia's Economic and Security Regionalism: Old Constraints and New Prospects, University of Southern California.

Arellano, M. and Bond, S. (1991) 'Some tests of specification for panel data: Monte Carlo evidence and an application to employment equations', Review of Economic Studies 58(2): 277-297.

Arellano, M. and Bover, O. (1995) 'Another look at the instrumental variable estimation of errorcomponents models', Journal of Econometrics 68(1): 29-51.

Arena, M. (2008) 'Does insurance market activity promote economic growth? A cross-country study for industrialized and developing countries', Journal of Risk \& Insurance 75(4): 921-946.

Avram, K., Nguyen, Y. and Skully, M. (2010) Insurance and economic growth: A cross country examination, unpublished Working Paper.

Bain, J.S. (1951) 'Relation of profit rate to industry concentration: American manufacturing, 1936-1940', Quarterly Journal of Economics 65(3): 293-324.

Bain, J.S. (1956) Barriers to New Competition, their Character and Consequences in Manufacturing Industries, Cambridge, MA: Harvard University Press.

Bajtelsmit, V. and Bouzouita, R. (1998) 'Market structure and performance in private passenger automobile insurance', Journal of Risk and Insurance 65(3): 503-514.

Beenstock, M., Dickinson, G. and Khajuria, S. (1988) 'The relationship between property-liability insurance premiums and income: An international analysis', Journal of Risk and Insurance 55(2): 259-272.

Berger, A., Bonime, S., Covitz, D. and Hancock, D. (2000) 'Why are banks profits so persistent? The roles of product market competition, informational opacity, and regional/macroeconomic shocks', Journal of Banking and Finance 24(7): 1203-1235.

Browne, M.J., Chung, J.W. and Frees, E.W. (2000) 'International property-liability insurance consumption', Journal of Risk and Insurance 67(1): 73-90.

Brozen, Y. (1982) Concentration, Mergers and Public Policy, New York, NY: Macmillan.

Carroll, A. (1993) 'An empirical investigation of the structure and performance of the private workers' compensation market', Journal of Risk and Insurance 60(2): 185-207.

Caves, R.E. and Uekusa, M. (1976) Industrial Organization in Japan, Washington, D.C.: The Brookings Institution.

Chen, P., Lee, C.C. and Lee, C.F. (2011) 'How does the development of the life insurance market affect economic growth? Some international evidence', Journal of International Development, currently only available online through Wiley-Blackwell, http://onlinelibrary.wiley.com/doi/10.1002/jid.1765/full.

Chidambaran, N.K., Pugel, T. and Saunders, A. (1997) 'An investigation of the performance of the U.S. property-liability insurance industry', Journal of Risk and Insurance 64(2): 371-381.

Choi, P. and Weiss, M.A. (2005) 'An empirical investigation of market structure, efficiency, and performance in property-liability insurance', Journal of Risk and Insurance 75(4): 635-673.

Clarke, R. (1984) 'Profit margins and market concentration in U.K. manufacturing industry', Applied Economics 16: 57-71.

Clark, J. and Speaker, P. (1992) 'The impact of entry conditions on the concentration-profitability relationship in banking', Quarterly Review of Economics and Finance 32(4): 45-64.

Collins, N.R. and Preston, L.E. (1969) 'Price-cost margins and industry structure', Review of Economics and Statistics 51(3): 271-286. 
Cowling, K. and Waterson, M. (1976) 'Price-cost margins and market structure', Economica 43(171): $267-274$

Cummins, J.D., Denenberg, H.S. and Scheel, W.C. (1972) 'Concentration in the U.S. life insurance industry', Journal of Risk and Insurance 39(2): 177-199.

Cummins, J.D. and Nini, G. (2002) 'Optimal capital utilization by financial firms: Evidence from the property-liability insurance industry', Journal of Financial Services Research 21(1/2): 5-23.

Cummins, J.D. and Weiss, M.A. (1992) 'The structure, conduct and regulation of the property-liability insurance industry', in A.W. Kopcke and R.E. Randall (eds.) The Financial Condition and Regulation of Insurance Companies, Boston, MA: Federal Reserve Bank.

Ćurak, M., Lončar, S. and Poposki, K. (2009) 'Insurance sector development and economic growth in transition countries', International Research Journal of Finance and Economics 34(December): $29-41$.

de Haan, L. and Kates, J. (2010) 'Are non-risk based capital requirements for insurance companies binding?' Journal of Banking \& Finance 34(7): 1618-1627.

Demsetz, H. (1973) 'Industry structure, market rivalry and public policy', Journal of Law and Economics 16(1): 1-9.

Demsetz, H. (1974) 'Two systems of belief about monopoly', in H. Goldschmid, H. Mann and J. Weston (eds.) Industrial Concentration: The New Learning, Boston, MA: Little, Brown and Company.

Feuerstein, S. (2005) 'Collusion in industrial economics: A survey', Journal of Industry, Competition and Trade 5(3): 163-198.

Gardner, L.A. and Grace, M.F. (1993) 'X-efficiency in the US life insurance industry', Journal of Banking and Finance 17(2-3): 497-510.

Goldberg, L. and Rai, A. (1996) 'The structure-performance relationship for European banking', Journal of Banking and Finance 20(4): 745-771.

Haiss, P. and Sumegi, K. (2008) 'The relationship between insurance and economic growth in Europe: A theoretical and empirical analysis', Empirica 35(4): 405-431.

Harris, F. (1986) 'Market structure and price-cost performance under endogenous profit risk', Journal of Industrial Economics 35(1): 35-59.

Jacquemin, A., de Ghellinck, E. and Huveneers, C. (1980) 'Concentration and profitability in a small open economy', Journal of Industrial Economics 29(2): 131-144.

Jenny, R. and Weber, A.P. (1976) 'Profit rates and structural variables in French manufacturing industries', European Economic Review 7(2): 187-206.

Joskow, P. (1973) 'Cartels, competition and regulation in the property-liability insurance industry', Bell Journal of Economics and Management Science 4(2): 375-427.

Lai, G.C. and Limpaphayom, P. (2003) 'Organizational structure and performance: Evidence from the nonlife insurance industry in Japan', Journal of Risk and Insurance 70(4): 735-757.

Li, D., Moshirian, F., Nguyen, P. and Wee, T. (2007) 'The demand for life insurance in OECD countries', Journal of Risk and Insurance 74(3): 637-652.

Liebenberg, A. and Sommer, D. (2008) 'Effects of corporate diversification: Evidence from the propertyliability insurance industry', Journal of Risk and Insurance 75(4): 893-919.

Ma, Y. and Pope, N. (2003) 'Determinants of international insurers' participation in foreign non-life market', Journal of Risk and Insurance 70(2): 235-248.

Mann, H.M. (1966) 'Seller concentration, barriers to entry, and rates of return in 30 industries', Review of Economics and Statistics 48(3): 296-307.

Molyneux, P. and Teppet, J.L. (1993) 'Structure-conduct-performance in EFTA banking markets', Bank en Financiewezen 3: 133-137.

Moshirian, F. (1997) 'Foreign direct investment in insurance services in the United States', Journal of Multinational Financial Management 7(2): 159-173.

Neumann, M., Bobel, I. and Haid, A. (1985) 'Domestic concentration, foreign trade and economic performance', International Journal of Industrial Organization 3(1): 1-19.

Nicholson, W. (1995) Microeconomic Theory: Basic Principles and Extensions, New York, NY: The Dryden Press.

Orr, D. (1974) 'An index of entry barriers and its application to the market structure-performance relationship', Journal of Industrial Economics 23(1): 39-50.

Outreville, J.F. (1990a) 'The relationship between insurance, financial development and market structure in developing countries an international cross-section study', UNCTAD Review, 53-69. 
Outreville, J.F. (1990b) 'The economic significance of insurance markets in developing countries', Journal of Risk and Insurance 18(3): 487-498.

Outreville, J.F. (1996) 'Life insurance markets in developing countries', Journal of Risk and Insurance 63(2): 263-278.

Peltzman, S. (1977) 'The gains and losses from industrial concentration', Journal of Law and Economics 20(2): 229-263

Pilloff, S.J. and Rhoades, S.A. (2002) 'Structure and profitability in banking markets', Review of Industrial Organization 20(1): 81-98.

Pope, N. and Ma, Y. (2008) 'The market structure-performance relationship in the international insurance sector', Journal of Risk and Insurance 75(4): 947-966.

Porter, M.E. (1980) Competitive Strategy: Techniques for Analyzing Industries and Competitors, New York, NY: The Free Press.

Porter, M.E. (2008) 'The five competitive forces that shape strategy', Harvard Business Review 86(1): 78-93.

Qualls, D. (1972) 'Concentration barriers to entry and long-run economic profit margins', Journal of Industrial Economics 20(2): 146-158.

Skipper, H. (1998) International Risk and Insurance: An Environmental-Managerial Approach, Boston, MA: Irwin/McGraw Hill.

Skipper, H. (2001) 'Liberalization of insurance market: Issues and concerns', in R.E. Litan, P. Masson, and M. Pomerleano (eds.) Open Doors: Foreign Participation in Financial Systems in Developing Countries, World Bank/IMF/Brookings Emerging Market Series. Washington, D.C.: The Brookings Institution.

Sommer, D.W. (1996) 'The impact of firm risk on property-liability insurance prices', Journal of Risk and Insurance 63(3): 501-514.

Stigler, G.L. (1964) 'A theory of oligopoly', Journal of Political Economy 72(1): 44-61.

Swiss Reinsurance Company (Swiss Re) (2008) World Insurance in 2007: Emerging Markets Leading the Way, sigma no. 3, Zurich, Switzerland: Swiss Reinsurance Company.

Swiss Reinsurance Company (Swiss Re) (2009) World Insurance in 2008: Life Premiums Fall in the Industrialised Countries-Strong Growth in the Emerging Economies, sigma no. 3, Zurich, Switzerland: Swiss Reinsurance Company.

Tsutsui, Y., Satake, M. and Uchida, H. (2006) Efficiency Structure Hypothesis versus Structure-ConductPerformance Hypothesis Revisited, white paper, Tokyo, Japan: Research Institute of Economy, Trade and Industry.

Weiss, L.W. (1974) 'The concentration-profits relationship and antitrust', in H. Goldschmid, H. Mann and J. Weston (eds.) Industrial Concentration: The New Learning, Boston, MA: Little, Brown and Company.

Ye, D., Li, D., Chen, Z., Moshirian, F. and Wee, T. (2009) 'Foreign participation in life insurance markets: Evidence from OECD countries', Geneva Papers on Risk and Insurance-Issues and Practice 34(3): 466-482.

Zheng, W., Liu, Y. and Deng, Y. (2009) 'A comparative study of international insurance market', Geneva Papers on Risk and Insurance-Issues and Practice 34(1): 85-99.

\section{About the Authors}

Yu-Luen Ma is a professor of Risk Management and Insurance at Katie School of Insurance and Financial Services at Illinois State University, U.S. She teaches Introduction to Risk and Insurance and Risk Management. Dr Ma received her MS degree in Actuarial Science and PhD degree in Risk Management and Insurance from The University of Wisconsin-Madison. Her main research interests include insurance company operation, insurance regulation, risk management and the global insurance market.

Nat Pope, Chartered Property Casualty Underwriter, Associate in Risk Management and Chartered Financial Consultant, is an associate professor of Risk Management 
and Insurance at Katie School of Insurance and Financial Services at Illinois State University. Dr Pope holds degrees from the Thunderbird School of Global Management (MBA) and the University of Wisconsin-Madison (MS and PhD).

Raymond Yeung is Senior Economist with Australia and New Zealand Banking Group (ANZ) based in Hong Kong. Prior to joining ANZ, he was Deputy Head of Economic Research at Swiss Re, covering insurance market developments in Asian markets. Dr. Yeung received his PhD degree in econometrics from Queen's University, Canada. $\mathrm{He}$ is a holder of Financial Risk Manager (FRM). 